\title{
STIMULASI PENYUSUNAN PERANGKAT PEMBELAJARAN KURIKULUM 2013 PAUD BAGI PENDIDIK PAUD DI KECAMATAN BANGUNTAPAN BANTUL
}

rina wulandari (rina_wulandari@uny.ac.id ); nur hayati (nurhayati@uny.ac.id) muthmainnah (muthmainah@uny.ac.id); arumi savitri fatimaningrum (arumi@uny.ac.id)

\begin{abstract}
Abstrak
Kegiatan stimulasi Penyusunan Perangkat Pembelajaran Kurikulum 2013 PAUD yang bekerja sama dengan Himpaudi Kecamatan Banguntapan, Bantul bertujuan untuk memberikan tambahan wawasan tentang penilaian pembelajaran. Metode penelitian ini adalah penelitian tindakan institusional yang dilaksanakan sebanyak dua siklus. Subyek penelitian sebanyak 84 pendidik PAUD di Kabupaten Bantul. Tindakan stimulasi diukur dengan menggunakan teknik tes, yaitu pretest pada pra tindakan dan pottest setelah tindakan siklus 2. Analisis pretest menunjukkan bahwa terdapat 8 orang (14\%) pada kategori tinggi, 41 orang (72\%) pada kategori sedang, dan 8 orang (14\%) pada kategori rendah. Analisis posttest menunjukkan bahwa terdapat 8 orang (14\%) pada kategori tinggi, 45 orang $(79 \%)$ pada kategori sedang, dan 4 orang (7\%) pada kategori rendah. Berdasarkan hasil penelitian ini dapat disimpulkan bahwa terdapat peningkatan kemampuan pendidikan dalam menyusun perangkat pembelajaran meskipun hanya sebesar $7 \%$ pada kategori sedang.
\end{abstract}

Kata kunci: perangkat penilaian, kurikulum 2013 PAUD, perangkat pembelajaran.

\section{Abstract}

The stimulation for the Preparation of Learning Tools for the 2013 PAUD Curriculum in collaboration with Himpaudi in Banguntapan District, Bantul aims to provide additional insight into the assessment of learning. The activity was carried out in as many as two activity sessions with the agenda of delivering material in the first session and workshop in the second session. The workshop activity was attended by 84 participants consisting of PAUD educators, Himpaudi daily administrators, and representatives from the Bantul Regency Dikpora Service. The effectiveness of PPM activities is measured using test techniques, namely the pretest and the pottest. Pretest analysis showed that there were 8 people $(14 \%)$ in the high category, 41 people (72\%) in the moderate category, and 8 people $(14 \%)$ in the low category. Posttest analysis showed that there were 8 people (14\%) in the high category, 45 people (79\%) in the medium category, and 4 people (7\%) in the low category. From these results it can be concluded that there was no significant change from the implementation of the 2013 PAUD Curriculum Learning Workshop Workshop.

Keywords: assessment tools, 2013 PAUD curriculum, preparation of learning devices 


\section{PENDAHULUAN}

Kurikulum yang paling banyak dipahami oleh pendidik PAUD dalam kurun waktu 10 tahun ini adalah Kurikulum 2004. Menurut beberapa pendidik PAUD merasa mudah menerapkan kurikulum tersebut karena cukup lama menekuni dan tema serta indikator sudah ditentukan oleh perancang kurikulum dari Dinas Pendidikan. Dengan demikian guru tinggal menerapkan di kurikulum sekolah tanpa banyak kesulitan. Namun pada perjalanan selanjutnya terbitlah Kurikulum 2010 hasil dari Permendiknas Nomor 58 Tahun 2009 tentang Standar Nasional Pendidikan Anak Usia Dini. Beberapa guru mulai belajar memahami Kurikulum 2010 yang dirasa lebih banyak menuntut kreativitas guru dalam membuat indikator. Pada akhirnya banyak guru yang memadukan indikator di Kurikulum 2004 yang tidak semuanya sesuai dengan Kurikulum 2010. Beberapa masukan mulai bermunculan hingga pada tahun 2014 ditetapkan Permendikbud Nomor 137 Tahun 2014 tentang Standar Nasional Pendidikan Anak Usia Dini.

Jika dikaji dari segi waktu, perubahan dan perbaikan kurikulum tersebut bisa dianggap wajar seiring dengan perubahan yang terjadi. Tetapi ketidakwajaran muncul tatkala perubahan dan perbaikan kurikulum tersebut tidak berdampak pada peningkatan kualitas dan relevansi pendidikan dengan tuntutan dan kebutuhan masyarakat, bahkan terjadi sebaliknya di mana hasil pendidikan menurun kualitasnya.

Berbagai upaya telah banyak dilakukan, namun hasil yang diperoleh sampai saat ini belumlah menggembirakan. Salah satu upaya yang saat ini sedang dilakukan adalah melakukan sosialisasi kurikulum. Pada tahun 2014 mulai diberlakukan Kurikulum 2013 di tingkat Pendidikan Anak Usia Dini, namun sampai tahun
2015 belum semua lembaga PAUD melaksanakan Kurikulum 2013 karena berbagai kendala salah satunya belum pernah mendapatkan sosialisasi. Kendala tersebut banyak dihadapi oleh lembaga PAUD yang terletak di daerah terpencil dan sering kesulitan mengakses informasi dari Dinas Pendidikan Kebudayaan maupun dari Lembaga Pendidikan Tinggi seperti UNY.

Sesuai dengan Peraturan Menteri Pendidikan dan Kebudayaan Nomor 137 Tahun 2014 tentang Standar Nasional Pendidikan Anak Usia Dini, Kompetensi Guru PAUD mencakup kompetensi pedagogik, kepribadian, sosial, dan profesional. Salah satu kompetensi pedagogik yang harus dimiliki oleh pendidik PAUD adalah merancang kegiatan pengembangan anak usia dini berdasarkan kurikulum. Guru akan mampu merancang kurikulum apabila memahami bagaimana mengembangkan tema dan merancang kegiatan bermain dalam bentuk program tahunan, semester, mingguan dan harian sesuai dengan kebutuhan anak usia dini.

Kondisi yang terjadi di lapangan masih banyak pendidik PAUD yang belum memahami cara mengembangkan kurikulum yang sesuai dengan kebutuhan anak karena pada kurikulum sebelumnya guru mengembangkan kurikulum di sekolah yang sudah dibuat oleh tim IGTK atau Himpaudi setempat. Berdasarkan realita tersebut perlu diadakan sosialisasi Kurikulum 2013 sekaligus workshop yang berkala agar semua pendidik PAUD dapat memahami perangkat kurikulum yang isinya sedikit berbeda dengan kurikulum-kurikulum sebelumnya. Kegiatan workshop yang berkala tersebut juga dapat meningkatkan kualitas kompetensi pedagogik guru yang harapannya dapat meningkatkan kompetensi lainnya yang dapat berimbas pada peningkatan kemampuan anak usia dini secara merata.

METODE KEGIATAN PPM

A. Kerangka Pemecahan Masalah 
Selama ini pendidik PAUD mempunyai peran yang luar biasa untuk menstimulasi dan mengembangkan potensi anak usia dini. Pendidik PAUD selama ini sudah mampu merancang kegiatan pembelajaran berdasarkan Kurikulum 2004 dan Kurikulum 2010. Namun tidak semua pendidik PAUD mampu menyusun perencanaan pembelajaran berbasis Kurikulum 2013. Hal tersebut dapat dimaklumi karena sosialisasi Kurikulum 2013 belum menjangkau ke wilayah yang terpencil. Sehingga masih banyak pendidik PAUD yang merancang kegiatan pembelajaran berdasarkan Kurikulum 2010.

Kurikulum PAUD sesuai dengan Pedoman Perencanaan Pembelajaran Anak Usia Dini (Direktorat Pembinaan PAUD, 2014) adalah seperangkat rencana dan pengaturan mengenai tujuan, isi, dan bahan pengembangan serta cara yang digunakan sebagai pedoman penyelenggaraan kegiatan pengembangan untuk mencapai tujuan pendidikan tertentu. Kurikulum PAUD terdiri dari perencanaan program semester berupa pengembangan tema, RPPM dan RPPH.

Perencanaan program semester berisi daftar tema satu semester termasuk alokasi waktu setiap tema dengan oleh pendidik/ pengasuh pada setiap hari atau sesuai dengan program lembaga. Komponen RPPH, antara lain: tema/ sub tema/ sub-sub tema, alokasi waktu, hari/ tanggal, kegiatan pembukaan, kegiatan inti, dan kegiatan penutup. RPPH adalah perencanaan program harian yang akan dilaksanakan oleh pendidik/pengasuh pada setiap hari atau sesuai dengan program lembaga. Komponen RPPH, antara lain: tema/ sub tema/ sub-sub tema, alokasi waktu, hari/ tanggal, kegiatan pembukaan, kegiatan inti, dan kegiatan penutup.

Berdasarkan kondisi tersebut, maka pemecahan masalah yang diajukan dalam PPM ini adalah dengan menyelenggarakan kegiatan dan menyesuaikan hari efektif kalender pendidikan yang bersifat fleksibel. Tema berfungsi sebagai wadah yang berisi bahan kegiatan untuk mengembangkan potensi anak dan menyatukan seluruh kompetensi dalam satu kesatuan yang lebih berarti, memperkaya wawasan dan perbendaharaan kata anak sehingga pembelajaran menjadi lebih bermakna. Penentuan tema dapat dikembangkan oleh pendidik PAUD mengacu pada contoh tema yang ada dalam panduan.

Perencanaan program mingguan merupakan rencana kegiatan yang disusun untuk pembelajaran selama satu minggu. Perencanaan kegiatan mingguan dapat berbentuk jaringan tema (web). Jaringan tema berisi proyek- proyek yang akan dikembangkan menjadi kegiatankegiatan pembelajaran. Pada akhir satu atau beberapa tema dapat dilaksanakan kegiatan puncak tema yang menunjukkan prestasi peserta didik. Puncak tema dapat berupa kegiatan antara lain membuat kue/makanan, makan bersama, pameran hasil karya, pertunjukan, panen tanaman, dan kunjungan.

Rencana

pelaksanaan pembelajaran harian (RPPH) adalah perencanaan program harian yang akan dilaksanakan

workshop Kurikulum 2013 bagi pendidik-pendidik PAUD di daerah terpencil agar mereka mengetahui bagaimana cara menyusun perencanaan pembelajaran mulai dari mengembangkan tema, membuat RPPM dan RPPH yang tematik dan saintifik sesuai dengan kebutuhan anak didiknya. Adapun alur pemecahan masalah dapat digambarkan dalam skema pada Gambar 1 berikut ini: 


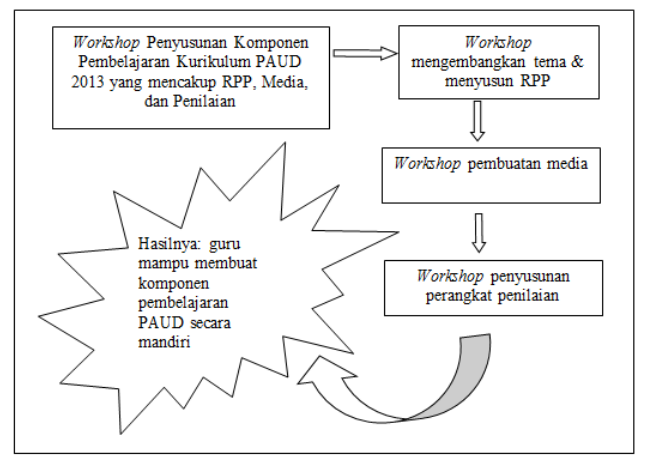

Gambar 1. Kerangka Pemecahan Masalah

\section{B. Khalayak sasaran}

yang telah disampaikan sebelumnya. Materi workshop meliputi: 1) Pengembangan tema pembelajaran yang tematik, pembuatan RPPM dan RPPH; 2) Pembuatan media, dan 3) Penyusunan perangkat penilaian. Pelaksanaan kegiatan diadakan sebanyak dua kali pertemuan dengan jumlah total 20 jam.

\section{HASIL PELAKSANAAN \\ KEGIATAN PPM}

A. Hasil Pelaksanaan Kegiatan

1. Deskripsi peserta

Kegiatan PPM Workshop

Penyusunan Komponen Pembelajaran Kurikulum PAUD 2013ini diikuti oleh 84 pendidik PAUD yang ada di wilayah Kecamatan Banguntapan, Bantul. Peserta berasal dari 50 institusi Pendidikan Anak Usia Dini yang ada, terdiri dari $37 \mathrm{~KB}$ (74\%), 5 SPS (10\%), 4 PAUD (8\%), dan 4 TPA (8\%). Kegiatan ini juga dihadiri oleh Drs. Suyanta selaku perwakilan dari Dinas Dikpora Kabupaten Bantul. Sebaran peserta kegiatan PPM dapat dilihat pada Gambar 2 berikut ini:
Khalayak sasaran yang akan dituju dalam pelatihan ini adalah 60 orang pendidik PAUD yang ada di wilayah kerja Kecamatan Banguntapan Kabupaten Bantul.

\section{Metode Kegiatan}

Kegiatan dilaksanakan dalam bentuk ceramah dan workshop. Metode ceramah digunakan dalam mentransfer pemahaman peserta mengenai Kurikulum PAUD 2013 dan komponen pembelajarannya. Metode workshop digunakan untuk mengimplementasikan pemahaman pendidik PAUD mengenai materi

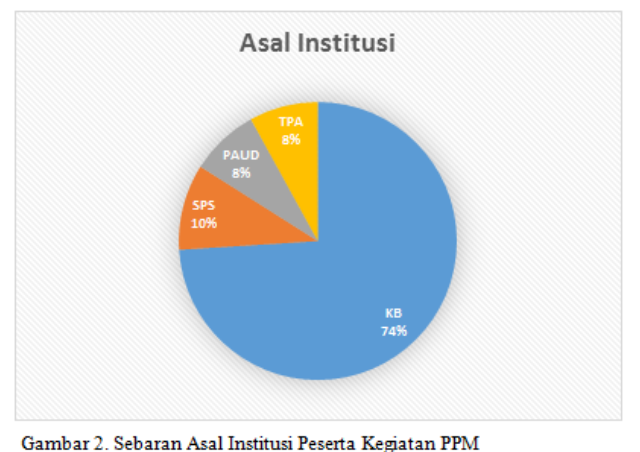

Gambar 2. Sebaran Asal Institusi Peserta Kegiatan PPM

\section{Deskripsi kegiatan \& materi}

Kegiatan dilaksanakan dalam bentuk ceramah dan workshop. Metode ceramah digunakan dalam mentransfer pemahaman peserta mengenai Kurikulum PAUD 2013 dan komponen pembelajarannya. Metode workshop digunakan untuk mengimplementasikan pemahaman pendidik PAUD mengenai materi yang telah disampaikan sebelumnya. Materi workshop meliputi: 1) Pengembangan tema pembelajaran yang tematik, pembuatan RPPM dan RPPH; 2) Pembuatan media, dan 3) Penyusunan perangkat penilaian. Pelaksanaan kegiatan diadakan sebanyak dua (2) kali pertemuan dengan jumlah total 20 jam.

\section{Deskripsi hasil pretest dan posttest}




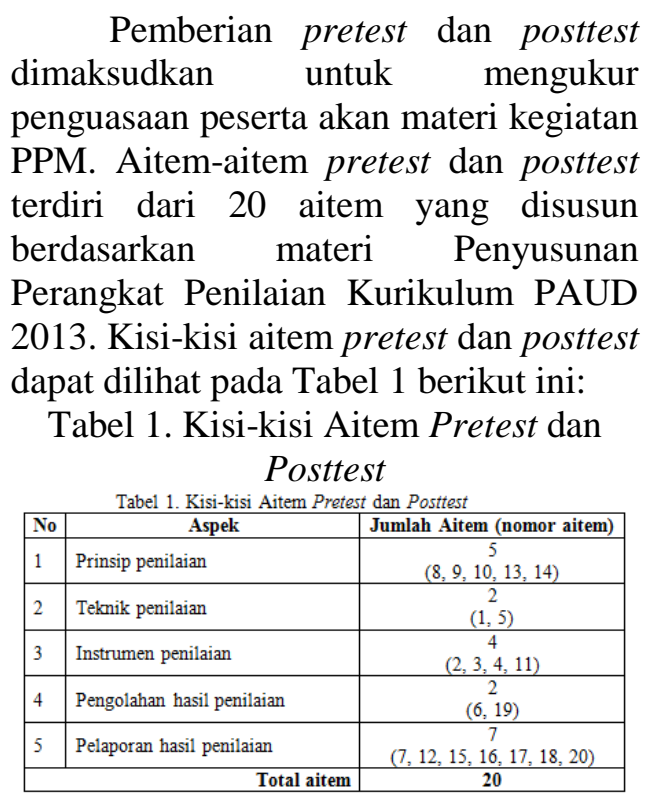

Pretest diberikan di awal kegiatan, tepatnya sebelum pemaparan materi dari narasumber. Sementara untuk posttest diberikan di akhir kegiatan setelah Workshop Penyusunan Perangkat Pembelajaran. Dari total 84 peserta kegiatan PPM, peserta yang mengikuti seluruh proses pretest dan posttest adalah sebanyak 57 peserta (69\%), sisanya ada yang hanya mengikuti pretest saja atau posttest saja. Hal ini disebabkan karena ada peserta yang terlambat hadir di pertemuan pertama dan ada peserta yang meminta ijin tidak bisa mengikuti hingga akhir rangkaian kegiatan. Untuk itu hasil tes yang akan dianalisis berasal dari 57 peserta kegiatan PPM.

Kategorisasi hasil pretest dan posttest dibuat menjadi tiga bagian, yaitu tinggi, sedang, dan rendah berdasarkan distribusi kurva normal dengan menggunakan rumus deviasi standar (Azwar, 2003).

\section{a. Kategorisasi Skor Pretest}

Dengan menggunakan bantuan program excel dari Microsoft Office Professional Plus 2013 didapatkan hasil mean sebesar 11,23 dan standar deviasi 2,38. Pada Tabel 2 berikut ini dapat dilihat kategori skor pretest berdasarkan klasifikasi hipotesis.
Tabel 2. Kategorisasi Skor Pretest

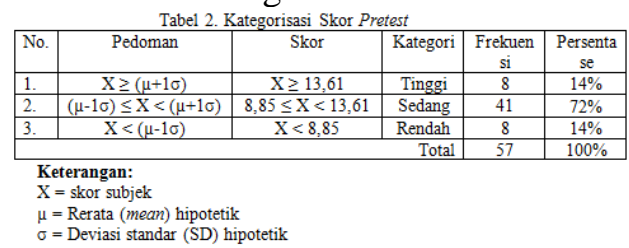

Keterangan:

$\mathrm{X}=$ skor subjek

$\mu=\operatorname{Rerata}($ mean) hipotetik

$\sigma=$ Deviasi standar (SD) hipotetik

Berdasarkan hasil kategori yang telah dilakukan, dapat diketahui bahwa terdapat 8 orang $(14 \%)$ yang memiliki hasil pretest pada kategori tinggi, 41 orang $(72 \%)$ yang memiliki hasil pretest pada kategori sedang, dan 8 orang (14\%) yang memiliki hasil pretest pada kategori rendah. Berdasarkan hasil tersebut dapat disimpulkan bahwa sebagian besar peserta pada tahapan awal PPM berada dalam kategori sedang pada penguasaan Penyusunan Perangkat Penilaian.

b. Kategorisasi Skor Posttest

Dengan menggunakan bantuan program excel dari Microsoft Office Professional Plus 2013 didapatkan hasil mean sebesar 11,81 dan standar deviasi 1,95. Pada Tabel 3 berikut ini dapat dilihat kategori skor posttest berdasarkan klasifikasi hipotesis.

Tabel 3 Kategorisasi Skor Posttest

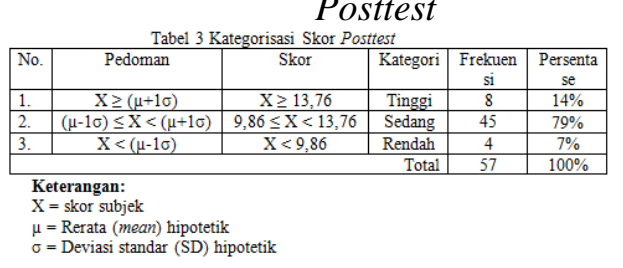

Keterangan:

$\mathrm{X}=$ skor subjek

$\mu=\operatorname{Rerata}($ mean) hipotetik

$\sigma=$ Deviasi standar (SD) hipotetik

Berdasarkan hasil kategori yang telah dilakukan, dapat diketahui bahwa terdapat 8 orang (14\%) yang memiliki hasil pretest pada kategori tinggi, 45 orang $(79 \%)$ yang memiliki hasil pretest pada kategori sedang, dan 4 orang $(7 \%)$ yang memiliki hasil pretest pada kategori 
rendah. Berdasarkan hasil tersebut dapat disimpulkan bahwa sebagian besar peserta pada tahapan akhir PPM berada dalam kategori sedang pada penguasaan Penyusunan Perangkat Penilaian.

Dari hasil kategorisasi hasil pretest dan posttest dapat ditampilkan bersama pada Gambar 3 berikut ini:

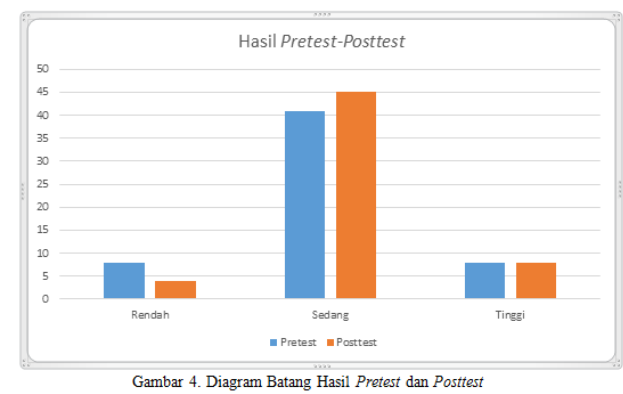

Gambar 4. Diagram Batang Hasil Pretest dan Posttest

Dari Gambar 4 di atas dapat disimpulkan bahwa sebagian besar peserta kegiatan PPM berada dalam kategori sedang dalam penguasaan materi Penyusunan Perangkat Penilaian.

\section{PEMBAHASAN}

Hasil PPM ini menunjukkan bahwa pemahaman peserta berada pada kategori sedang. Salah satu faktor penyebabnya adalah perlunya paparan wawasan kepada guru secara mendalam khususnya pada konsep pendidikan seni. Penilaian pada aspek seni, mempunyai karakter yang berbeda dengan aspek lainnya. Sebagaimana diketahui bahwa tujuan pendidikan seni pada anak usia dini adalah kebebasan imajinasi. Tujuan ini sering bercampur dengan indikator kemampuan pada aspek motorik halus. Tentulah hal ini sangat berbeda.

Mengapa kekebasan imajinasi menjadi konsep utama pada pembelajaran seni pada anak? Dalam seni rupa, hal ini ada kaitannya dengan karakter perkembangan grafik yang sedang dialami anak. Ebenezer Cooke dalam Kenneth M Lansing (1976: 137147) menyatakan bahwa dalam simbolisasi ide melalui coretan-coretan pena, terdapat: 1) Tahap Scribbling (2-4 tahun), 2). Tahap figurative (3-12 tahun). Dalam tahap figurative terdapat sub yaitu the early figurative substage (37 tahun). Pada tahap Scribbling, hasil karya gambar yang dihasilkan anak bahkan dapat dikatakan tidak mirip dengan benda asli. Sulit dipahami secara subjektifitas guru/ orang dewasa. Kita dapat mengetahui ide gambar anak pada tahap Scribbling jika menanya ke anak. Tahap figuratif dengan rentang usia mulai 3 tahun, hasil gambar yang dikerjakan anak dapat dikatakan 'sedikit mirip'. Pemahaman inilah yang mestinya diberikan kepada guru-guru agar supaya 'adil' ketika menilai seni pada anak. Banyak warna belum tentu ada ide baru/ gagasan di dalamnya. Kertas kosong, belum tentu tidak punya ide. Dengan dimilikinya wawasan ini maka ketika menilai seni pada anak tidak terjebak pada aspek kognitif dan psikomotor, walaupun memang kedua ranah ini ada dalam seni.

Dapat dibayangkan bahwa hari senin, anak "hanya" membuat satu coretan. Hari selasa, juga terulang lagi. Namun suatu hari, si anak mau menggambar dan hasilnya mirip benda asli. Bagaimana guru akan menilai? Apakah anak dinilai tidak bisa berseni hanya karena menorehkan satu garis di kertas putih? Tentu saja jawabnnya adalah tidak. Hal ini dikarenakan rentang usia dan teknik penilaian yang diperlukan pemahaman dan perhatian khusus sesuai konsep seni yaitu kebebasan imajinasi.

\section{Evaluasi}

Evaluasi kerja yang akan dilaksanakan meliputi evaluasi pemahaman peserta terhadap materi. Evaluasi ini dilaksanakan dengan menggunakan angket dan FGD. Evaluasi diawali dengan pengisian angket terkait pelaksanaan kegiatan, selanjutnya dilanjutkan dengan diskusi secara mendalam antar peserta secara berkelompok (Focus Group Discusion). 
Evaluasi tahap kedua adalah evaluasi terhadap hasil workshop berupa masukan dan perbaikan: 1) Pengembangan tema, RPPM dan RPPH; 2) Media, dan 3) Perangkat penilaian yang telah dikerjakan oleh peserta. Di samping itu dalam pelaksanaan kegiatan ini juga dibuat progress report dalam setiap tahapan kegiatan.

\section{Faktor Pendukung}

1. Antusiasme peserta kegiatan yang bisa dilihat dari jumlah peserta yang melebihi target kegiatan yaitu tercapai 84 peserta dari target 60 peserta kegiatan PPM.

2. Kerjasama yang baik dengan HIMPAUDI Wilayah Kecamatan Banguntapan dalam menyebarkan publikasi dan mempersiapkan fasilitas pendukung pelaksanaan kegiatan PPM.

3. Adanya narasumber dari instruktur nasional yaitu ibu Ir. Siti Donatirin, M.Pd. yang menyampaikan materi dasar Pengembangan Perangkat Pembelajaran Kurikulum 2013 PAUD.

4. Profesionalisme, penguasaan materi, serta keterampilan teknis yang dimiliki oleh dosen-dosen Jurusan PAUD FIP UNY sebagai fasilitator workshop Pengembangan Perangkat Pembelajaran Kurikulum 2013 PAUD yang juga merupakan instruktur PLPG dan PPG PAUD.

5. Keterlibatan mahasiswa Semester VI sebagai asisten fasilitator workshop yang sebelumnya juga telah memiliki kemampuan menyusun Perangkat Pembelajaran Kurikulum 2013 PAUD yang telah didapatkan pada mata kuliah Micro Teaching (PPL I).

\section{Penghambat Kegiatan}

1. Beberapa peserta belum dapat mengikuti seluruh kegiatan PPM dikarenakan adanya kegiatan lain yang berbarengan sehingga masih ada yang meninggalkan lokasi sebelum kegiatan berakhir.

2. Belum bisa mengukur perubahan penguasaan materi dari seluruh peserta kegiatan. Baru terdapat $69 \%$ dari keseluruhan peserta yang dapat mengikuti pretest dan posttest. Sisanya $31 \%$ tidak memiliki kedua skor pretest dan posttest karena terlambat hadir atau harus meninggalkan lokasi kegiatan karena adanya kegiatan lain yang bersamaan waktunya.

3. Belum adanya peningkatan yang signifikan dari hasil pretest ke posttest, kemungkinan besar hal ini disebabkan tidak seluruh peserta mengisi posttest.

\section{PENUTUP}

\section{A. Kesimpulan}

Kegiatan PPM Workshop

Penyusunan Perangkat Pembelajaran Kurikulum 2013 PAUD telah dilaksanakan dengan bekerja sama dengan Himpaudi Kecamatan Banguntapan, Bantul. Kegiatan PPM dilaksanakan sebanyak dua sesi kegiatan dengan agenda penyampaian materi pada sesi pertama dan workshop pada sesi kedua. Kegiatan workshop diikuti oleh 84 pesert yang terdiri atas pendidik PAUD, pengurus harian Himpaudi, dan perwakilan dari Dinas Dikpora Kabupaten Bantul. Efektivitas pelaksanaan kegiatan PPM diukur dengan menggunakan teknik tes, yaitu pretest dan pottest. Analisis pretest menunjukkan bahwa terdapat 8 orang (14\%) pada kategori tinggi, 41 orang (72\%) pada kategori sedang, dan 8 orang (14\%) pada kategori rendah. Analisis posttest menunjukkan bahwa terdapat 8 orang (14\%) pada kategori tinggi, 45 orang (79\%) pada kategori sedang, dan 4 orang $(7 \%)$ pada kategori rendah. Dari hasil ini dapat disimpulkan bahwa tidak ada perubahan yang signifikan dari pelaksanaan Workshop Penyusunan 
Perangkat Pembelajaran Kurikulum 2013

PAUD.

\section{B. Saran}

1. Perlu dilakukan penelitian lanjutan yang lebih memperhatikan faktorfaktor lain yang mempengaruhi kemampuan pendidik PAUD dalam melakukan penyusunan perangkat pembelajaran Kurikulum 2013 PAUD.

2. Kegiatan PPM perlu dilanjutkan secara kontinyu dan terjadwal sehingga para pendidik PAUD dapat didampingi mulai awal semester pada saat perencanan kegiatan hingga evaluasi dan penilaian yang biasanya dilakukan pada akhir semester.

\section{Daftar Pustaka}

Ansyar, M. (2015). Kurikulum Hakikat, Fondasi, Desain Pengembangan. Jakarta: Kencana Prenada Media Group.

Azwar, S. (2003). Reliablitas dan Validitas. Yogyakarta: Pustaka Pelajar.

Haenilah, E. (2015). Kurikulum dan Pembelajaran PAUD. Yogyakarta: Media Akademi.

Tim Direktorat Pembinaan PAUD. (2014). Pedoman Penyusunan Perencanaan Pembelajaran PAUD. Jakarta: Kementerian Pendidikan dan Kebudayaan RI, Direktorat Jenderal Pendidikan Anak Usia Dini, Nonformal, dan Informal.

Tim Penyusun Penilaian Pembelajaran PAUD. (2015). Pedoman Penilaian Pembelajaran PAUD. Jakarta: Kementerian Pendidikan dan Kebudayaan,
Direktorat Pendidikan Anak Usia Dini dan Pendidikan Masyarakat, Direktorat Pembinaan Pendidikan Anak Usia Diri.

Lansing, M Kenneth. 1976. Art, Artists, and Art Education. Kendal/ Hunt. Iowa. 